\title{
Efficacy of Dietary Selenium to Counteract Toxicity of Deoxynivalenol in Growing Broiler Chickens
}

\author{
Z. FAIXOVÁ ${ }^{1}, \breve{S}$. FAIX ${ }^{2}$, R. BOŘUTOVÁ ${ }^{2}$, L. LENG $^{2}$ \\ ${ }^{1}$ Department of Pathophysiology, University of Veterinary Medicine, Košice, Slovak Republic \\ ${ }^{2}$ Institute of Animal Physiology Slovak Academy of Sciences, Košice, Slovak Republic \\ Received January 29, 2007 \\ Accepted July 9, 2007
}

\begin{abstract}
Faixová Z, Š. Faix, R. Bořutová, L. Leng: Efficacy of Dietary Selenium to Counteract Toxicity of Deoxynivalenol in Growing Broiler Chickens. Acta Vet. Brno 2007, 76: 349-356.

The aim of this study was to evaluate the effect of deoxynivalenol on plasma indicators and efficacy of dietary selenium to counteract toxicity of deoxynivalenol in growing broiler chicks. Three groups of broilers were formed with 14 birds in each group. Three diets included control (0.2 ppm deoxynivalenol, $0.4 \mathrm{mg}$ selenium $/ \mathrm{kg}$ diet), deoxynivalenol-contaminated (3 ppm deoxynivalenol, $0.4 \mathrm{mg}$ selenium $/ \mathrm{kg}$ diet) and deoxynivalenol-contaminated (3 ppm deoxynivalenol) plus selenium-enriched yeast (1.4 mg selenium $/ \mathrm{kg} \mathrm{diet}$ ). After 6 weeks of feeding all birds were sacrificed and blood samples for chemical analyses were collected. Plasma calcium, chloride and alanine aminotransferase activity were significantly elevated and magnesium, total proteins, triglycerides and free glycerol were decreased in chicks fed deoxynivalenol-contaminated diet compared with those fed the control diet. Supplementation of selenium-enriched yeast to the diet reversed plasma levels of calcium, magnesium and alanine aminotransferase activity in chicks induced by dietary deoxynivalenol. Phosphorus, albumin and cholesterol levels and alkaline phosphatase, aspartate aminotransferase and lactate dehydrogenase activities were not affected by diets. The inclusion of selenium to DON-contaminated diet, however, did not completely alleviate toxic effect on protein and lipid metabolism by the liver. Supplementation of selenium-enriched yeast product counteracted most of the plasma indicator alterations caused by deoxynivalenol-contaminated diet in chicks.
\end{abstract}

Deoxynivalenol, chicken, plasma indices, selenium-enriched yeast

Fusarium species occur widely on plants. They are found in a variety of agricultural products mainly on corn, wheat and other cereal grains for human and animal consumption.

Although more than 100 Fusarium mycotoxins are known, those fusariotoxins of most concern based on toxicity and occurrence on a worldwide basis are trichothecenes, zearalenone, fumonisins and moniliformin.

Deoxynivalenol (DON) is the most prevalent trichothecene in crops used for food and feed production. Toxic effects of DON on animals have been well documented and concern mainly the immune system and the gastrointestinal tract (Rotter et al. 1996). The toxicity of DON is thought to be due to inhibition of protein synthesis and cytotoxicity was reported in a variety of cells (Parent-Massin 2004).

Trichothecenes are also known to interfere with the metabolism of membrane phospholipids and to increase liver lipid peroxides in vivo (Mezes et al. 1999).

The sensitivity to DON varies considerably between species. Poultry are more sensitive to DON than ruminants but less sensitive than pigs.

In order to avoid mycotoxicosis, several strategies have been investigated. The most frequently applied method for protecting animals against mycotoxicosis is the utilization of adsorbants mixed with the feed which are supposed to bind mycotoxins efficiently in the gastrointestinal tract. Many compounds have been tested for adsorptive effects on mycotoxins, but only few have proven successful (Swamy et al. 2002; Dvorska and Surai 2004; Diaz et al. 2005).

Address for correspondence:

Doc. MVDr. Zita Faixová, PhD.

Department of Pathology, Physiology and Genetics

University of Veterinary Medicine in Košice

Komenského 73

04181 Košice, Slovak Republic

Phone: +421915984704

E-mail: faixova@uvm.sk

http://www.vfu.cz/acta-vet/actavet.htm 
Since some mycotoxins are known to produce membrane damage through increased lipid peroxidation, the protective properties of antioxidant substances have been extensively used.

Selenium, some vitamins (A, C and E) and their precursors act as superoxide anion scavangers. For these reasons, these substances have been used as protecting agents against toxic effects of mycotoxins. The effect of selenium as protecting agent against toxic effects of mycotoxins has been reported by several researchers.

In a controlled study, Lin et al. (1994) observed that selenium is able to reduce in vitro toxic effects of T-2 toxin on cultured chicken embryonic chondrocytes. These findings are in agreement with the report of Shi et al. (1994). They demonstrated that selenium inhibits aflatoxin $\mathrm{B}_{1}$-DNA binding. The same authors (Shi et al. 1995) found in an in vitro study on cultured hamster ovary cells that sodium selenite and selenium enriched yeast extract protect cells from aflatoxin $\mathrm{B}_{1}$ cytotoxicity but not from mutagenicity.

However, much less information is available from studies on other mycotoxins, such as ochratoxin, zearalenone, deoxynivalenol, citrinin, moniliformin and fusaric acid.

The objective of this study was to evaluate the protective effect of selenium enriched product to counteract toxicity of deoxynivalenol in growing broiler chicks.

\section{Materials and Methods}

Animals, diets and treatments

Fourty-two chickens of Ross 308 hybrid broilers were randomly divided on the day of hatching into 3 groups (n =14). The birds were kept on the floor during the study. Chickens were reared under lighting regimen of 23L:1D. The initial room temperature of $32-23{ }^{\circ} \mathrm{C}$ was reduced every week by $3{ }^{\circ} \mathrm{C}$ to a final temperature of $23{ }^{\circ} \mathrm{C}$. All birds had free access to feed and water.

Birds were fed diets for 6 weeks which differed only in DON contamination and/or amount of selenium supplemented. Three diets included control ( $0.2 \mathrm{ppm}$ deoxynivalenol, $0.4 \mathrm{mg}$ selenium $/ \mathrm{kg}$ diet $)$, deoxynivalenolcontaminated (3 ppm deoxynivalenol, $0.4 \mathrm{mg}$ selenium $/ \mathrm{kg}$ diet) and deoxynivalenol-contaminated (3 ppm deoxynivalenol) plus Selplex ${ }^{\circledR}$ (Alltech Inc. USA), (1.4 mg selenium/kg diet).

To provide stable dietary contents of mycotoxins throughout the experiment, the chickens were fed only one type of diet HYD-02. The composition of this diet is given in Table 1.

Table 1. The composition of diet HYD-02

\begin{tabular}{|l|c|}
\hline Component & $\mathrm{g} \cdot \mathrm{kg}^{-1}$ \\
\hline Wheat ground, $10.5 \%$ of crude protein $(\mathrm{CP})$ & 260 \\
\hline Soya bean oil & 14 \\
\hline Maize ground $(8.3 \% \mathrm{CP})$ & 400 \\
\hline Soya bean extracted ground meal (45\% CP, $1.5 \%$ fat) & 273.5 \\
\hline Fish meal (72\% CP) & 12.5 \\
\hline Premix HYD-02 (vitamins and minerals) & 40 \\
\hline
\end{tabular}

$1 \mathrm{~kg}$ of diet contained: vitamin A $12450 \mathrm{IU}$; vitamin D3 $3800 \mathrm{IU}$; vitamin $\mathrm{K} 2.85 \mathrm{mg}$; vitamin E $61.2 \mathrm{mg}$; thiamine $5.6 \mathrm{mg}$; riboflavin $7.67 \mathrm{mg}$; pyridoxine $8.01 \mathrm{mg}$; cyanocobalamin $22.79 \mu \mathrm{g}$; niacin $69 \mathrm{mg}$; panthotenic acid $20.01 \mathrm{mg}$; biotin $0.34 \mathrm{mg}$; folic acid $1.81 \mathrm{mg}$; lysine $11.9 \mathrm{~g}$; methionine $5.0 \mathrm{~g}$; Zn $70.97 \mathrm{mg}$; I $0.81 \mathrm{mg}$; Co 0.06 mg; Mn 87.08 mg; Cu 13.98 mg; Fe 120.0 mg; Se 0.4 mg.

The final diets were obtained by mixing the basal diet supplied by Agrokonzult, s.r.o., the Slovak Republic (the part of HYD-02 diet before addition of $40 \%$ portion of maize) with control or contaminated maize. Maize used for the diets of control contained DON background level $0.5 \mathrm{mg} \cdot \mathrm{kg}^{-1}$ while zearalenone and 15-acetyldeoxynivalenol were below detection limits. Diets for groups 2 and 3 contained DONcontaminated maize at a concentration of $7.5 \mathrm{mg} \cdot \mathrm{kg}^{-1}$. Zearalenone and 15 -acetyldeoxynivalenol levels in the contaminated maize were 0.3 and $0.6 \mathrm{mg} \cdot \mathrm{kg}^{-1}$, respectively. Concentrations of $\mathrm{T}-2$ toxin, iso $\mathrm{T}-2$ toxin, T-2 triol, T-2 tetraol, HT-2 toxin, fusarenon-X, 3-acetyldeoxynivalenol, DAS, scirpentriol, nivalenol, 15acetylscirpentriol, neosolaniol, zearalenol, aflatoxins and fumonisins were below detection limits in both control and contaminated maize.

The mycotoxin contents in the basal diet (the part of HYD-02 diet before addition of $40 \%$ portion of control or 
contaminated maize) were found to be 0.05 and $0.0026 \mathrm{mg} \cdot \mathrm{kg}^{-1}$ for zearalenone and total aflatoxins, respectively. DON, T-2 toxin and total fumonisins were below the detection limit of the method used.

All experimental procedures with animals were in accordance with European Guidelines for care and use of animals for research purposes and they were approved by the local Ethic Committee.

Sample analysis

All birds were sacrificed and blood samples for chemical analyses were collected. Plasma was separated by centrifugation at $1600 \mathrm{~g}$ for $10 \mathrm{~min}$ and stored at $-20^{\circ} \mathrm{C}$ until analysis.

Alkaline phosphatase, alanine aminotransferase and aspartate aminotransferase activities and concentration of calcium, magnesium, chlorides, phosphorus, total proteins, albumin, cholesterol, triglycerides and free glycerol were determined by the colorimetric methods using spectrophotometric kits.

Mycotoxins in maize were detected using GC-MS method (Raymond et al. 2003). The mycotoxin contents in the basal diet (the part of HYD-02 diet before addition of $40 \%$ portion of control or contaminated maize) were analyzed using NOACK kits for ELISA with spectrophotometric evaluation. The concentration of selenium in diets was measured using the fluorometric method of Rodriguez et al. (1994).

The results are expressed as mean \pm S.E.M. Statistical significance was evaluated by one-way ANOVA test.

\section{Results}

Dietary suplementation of DON increased plasma alanine aminotransferase activity and decreased total proteins concentration (ALT $0.25 \pm 0.01$ to $0.47 \pm 0.01 \mu \mathrm{kat} \cdot \mathrm{l}^{-1}$, $P<0.01$, total protein $35.54 \pm 1.53$ to $18.59 \pm 1.92 \mathrm{~g} \cdot \mathrm{l}^{-1}, P<0.01$, Fig. 1$)$. Supplementation of selenium- enriched yeast to the contaminated diet reversed plasma alanine aminotransferase activity $\left(0.47 \pm 0.01\right.$ to $\left.0.25 \pm 0.02 \mu \mathrm{kat} \cdot \mathrm{l}^{-1}, P<0.01\right)$. Alkaline phosphatase and aspartate aminotransferase activities were not affected by diets (ALP $8.13 \pm 0.91,6.72 \pm 1.26,8.54 \pm 0.62 \mu \mathrm{kat} \cdot \mathrm{l}^{-1}, \mathrm{NS}, \mathrm{AST} 1.84 \pm 0.08,2.12 \pm 0.09,1.40$ $\left.\pm 0.08 \mu \mathrm{kat} \cdot \mathrm{l}^{-1}, \mathrm{NS}\right)$.

Plasma triglycerides and free glycerol levels were decreased in animals fed the diet containing $3 \mathrm{ppm}$ DON (triglycerides $0.59 \pm 0.04$ to $0.34 \pm 0.02 \mathrm{mmol} \cdot \mathrm{l}^{-1}, P<0.01$, free glycerol $0.48 \pm 0.04$ to $0.23 \pm 0.02 \mathrm{mmol} \cdot \mathrm{l}^{-1}, P<0.01$, Fig. 2). Plasma cholesterol concentration and lactate dehydrogenase activity, however, were not affected by diets (cholesterol $3.29 \pm 0.12,3.80 \pm 0.34,2.81 \pm 0.12 \mathrm{mmol} \cdot \mathrm{l}^{-1}$, NS, lactate dehydrogenase $\left.2.18 \pm 0.16,2.88 \pm 0.43,3.83 \pm 0.26 \mu \mathrm{kat} \cdot \mathrm{l}^{-1}, \mathrm{NS}\right)$.

There were no differences between groups in plasma albumin level $(12.3 \pm 0.17,15.8 \pm$ $\left.0.32,16.8 \pm 0.52 \mathrm{~g} \cdot \mathrm{l}^{-1}, \mathrm{NS}\right)$.

Plasma calcium and chloride levels were significantly higher and magnesium concentration was significantly lower in birds fed the diet containing 3 ppm (Table 2). Supplementation of selenium-enriched yeast to DON-contaminated diet reversed plasma levels of calcium and magnesium.

Inclusion of selenium-enriched yeast to DON-contaminated diet, however, did not completely alleviate the toxic effect on protein and lipid metabolism by the liver (triglycerides $0.34 \pm 0.02$ to $0.50 \pm 0.20 \mathrm{mmol} \cdot \mathrm{l}^{-1}, \mathrm{NS}$, free glycerol $0.23 \pm 0.02$ to $0.39 \pm$ $\left.0.01 \mathrm{mmol} \cdot \cdot^{-1}, \mathrm{NS}\right)$.

\section{Discussion}

The deoxynivalenol treatment significantly decreased plasma level of total protein of chicks. Our results are consistent with those of Kubena et al. (1988) who found decreased total protein level in broiler chicks exposed to a DON $(16 \mathrm{mg} / \mathrm{kg})$ contaminated diet from 1 to 3 weeks of age.

Bergsjø et al. (1993) reported a significant decrease in serum protein in growing pigs fed a diet containing $3.5 \mathrm{mg} / \mathrm{kg}$ DON. They considered that these effects may be secondary to the reduced feed uptake but the inhibition of protein synthesis may play some role, too. One of the toxicities of DON was thought to be derived from the inhibition of protein 


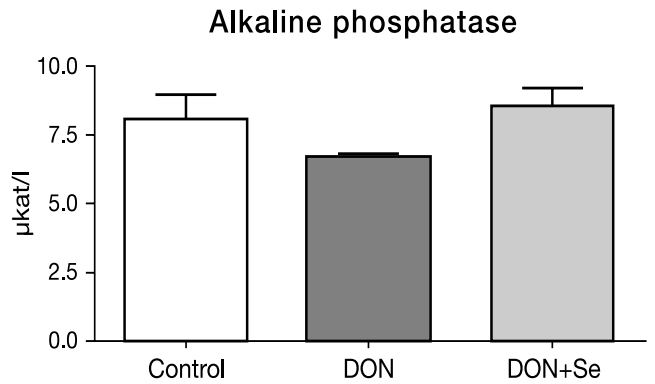

Alanine aminotransferase

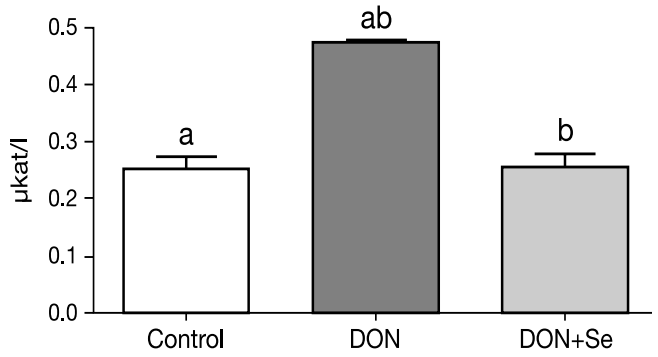

Aspartane aminotransferase

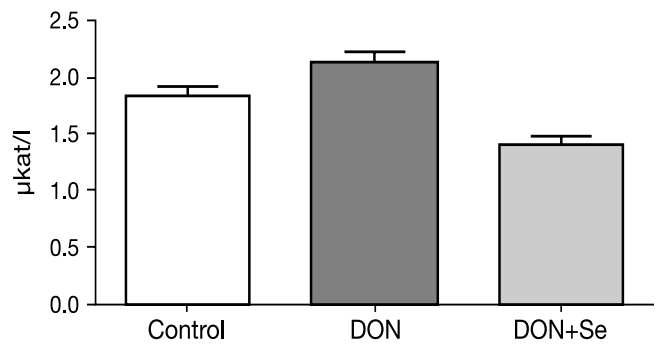

Total protein

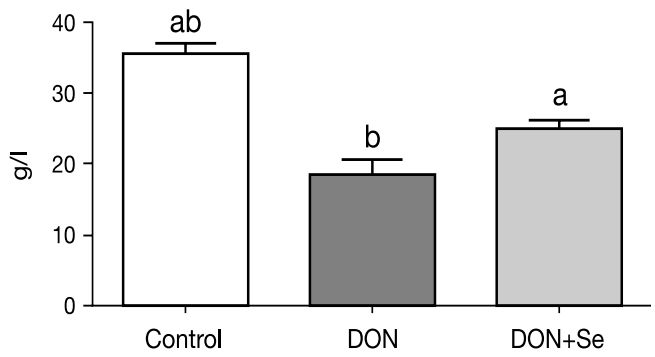

Fig. 1. Plasma alkaline phosphatase, alanine aminotransferase and aspartate aminotransferase activities and total protein concentration after DON and seleniumenriched yeast intake in chickens. Values are mean \pm S.E.M. $(n=14)$. Significant differences between columns are indicated by using the same superscript letter, $P<0.01$. synthesis (Rotter et al. 1996). These data were confirmed by Mikami et al. (2004).

We failed to demonstrate a protective effect of organic selenium against changes in protein metabolism in the liver induced by DON. Burguera et al. (1983), however, reported that selenium supplementation was effective in reducing the adverse effects of aflatoxin in turkey poults expressed by higher values of total protein.

The toxicity of DON was expressed through decreased plasma triglycerides and free glycerol in broiler chicks. These findings are in agreement with the previous reports of Kubena et al. (1987). DON has been reported to increase liver triglycerides and total liver lipid in White Leghorn hens fed a diet containing 0.25 or $0.70 \mathrm{ppm}$ DON for 86 or 135 days (Farnworth et al. 1983).

Our results showed that selenium in the diet was ineffective in reducing the adverse effects of DON on lipid metabolism.

Dietary inclusion of $3 \mathrm{ppm}$ DON resulted in increased plasma alanine aminotransferase activity, indicating liver damage. DON has also been reported to increase activities of aspartate aminotransferase, lactate dehydrogenase and gamma glutamyltransferase in broiler chicks fed DON at $15 \mathrm{mg} / \mathrm{kg}$, indicating possible tissue damage and leakage of the enzymes into the blood (Kubena et al. 1997). Similar results were observed in horses (Raymond et al. 2003) and piglets (Doll et al. 2005) fed Fusarium culture material.

Supplementation of organic selenium to the contaminated diet decreased plasma alanine aminotransferase activity. Similar results were observed by Atroshi et al. (1999) who reported that pretreatment with $\mathrm{Co} \mathrm{Q}_{10}$ (30 mg Co $\mathrm{Q}_{10} / \mathrm{kg}$ diet) together with carnitine $(2.8 \mathrm{mg}$ carnitine/ $\mathrm{kg}$ diet), alpha-tocopherol (30 IU vitamin $\mathrm{E} / \mathrm{kg}$ diet) and selenium (1 mg selenium as sodium selenite $/ \mathrm{kg}$ diet) decreased DNA damage and the activities of AST and ALT in the liver induced by fumonisin $\mathrm{B}_{1}$ in rats. 
Table 2. Effect of dietary inclusion of deoxynivalenol and selenium-enriched yeast on plasma indices in growing broiler chickens

\begin{tabular}{|l|c|c|c|}
\hline $\begin{array}{c}\text { Indicator } \\
\left(\mathrm{mmol} \cdot \mathrm{-}^{-1}\right)\end{array}$ & Control & DON & DON+Se \\
\hline Calcium & $1.73 \pm 0.13^{\mathrm{a}}$ & $3.36 \pm 0.35^{\mathrm{ab}}$ & $1.69 \pm 0.09^{\mathrm{b}}$ \\
\hline Magnesium & $1.02 \pm 0.07^{\mathrm{a}}$ & $0.35 \pm 0.02^{\mathrm{ab}}$ & $0.89 \pm 0.05^{\mathrm{b}}$ \\
\hline Chloride & $81.9 \pm 5.37^{\mathrm{ab}}$ & $114.4 \pm 4.37^{\mathrm{a}}$ & $107.9 \pm 1.28^{\mathrm{b}}$ \\
\hline Phosphorus & $3.01 \pm 0.23$ & $2.16 \pm 0.25$ & $3.01 \pm 0.73$ \\
\hline
\end{tabular}

Values are mean \pm S.E.M., $\mathrm{n}=14$. Significant differences within a row are indicated by using the same superscript letter, $P<0.01$.

In the present study, the administration of $3 \mathrm{ppm}$ DON to diet altered plasma calcium. Previous data of Bergsjø et al. (1993) reported a significant decrease in serum calcium and phosphorus in growing pigs fed a diet containing $3.5 \mathrm{mg} \mathrm{DON} / \mathrm{kg}$ diet. DON has also been reported to induce a weak hypocalcaemia in rats fed $1 \mathrm{mg} / \mathrm{kg}$ DON diet for 6 months, suggesting that calcium metabolism disorders during chronic action of mycotoxin could be partially associated with secondary vitamin D deficiency (Sergeev et al. 1990).

However, recently Gouze et al. (2006) reported that electrolytes in plasma appeared to be insensitive to a 4-week exposure to low DON in mice.

The discrepancy between these results and our data could be due to a number of factors, including sensitivity to DON between species, DON-concentration, DON source, animal genetics, sex and nutritional status.

Inclusion of organic selenium in DON-enriched diet of growing broiler chicks provided a significant protective effect against changes in calcium metabolism.

On the basis of many reports about antimycotoxin action of antioxidant compounds and our findings it may be concluded that nutritional approaches for protection against mycotoxins should include increased levels of methionine, selenium and vitamin supplementation of the affected diet. Mycotoxins, upon being absorbed, are detoxified in the liver, utilizing the glutathione system, which contains cystine (derivative of methionine). Hence the metabolic level of methionine is depleted, leading to poor growth and feed efficiency.

Higher levels of methionine, selenium and vitamin supplementation in feed, therefore, have been found to be beneficial.

The role of dietary antioxidants such as vitamin $\mathrm{C}, \mathrm{E}$ and selenium in preventing mycotoxin toxicity has attracted increasing attention at present and numerous trials are currently in progress to ascertain the benefits of these compounds in the diet.

Peng and Yang (2003) observed that sodium selenite is able to reduce in vitro the toxic effect of DON on cultured cardiomyocytes. Studies of Jakhar and Sadana (2004) showed that supplementation of selenium ( $5 \mathrm{ppm}$ sodium selenite) had some protective effect against the toxic effect of 1 ppm aflatoxin $B_{1}$ in Japanese quail.

However, McLeod et al. (1997) reported that rats fed a selenium-deficient diet were resistant to aflatoxin $\mathrm{B}_{1}$ than those fed a selenium-sufficient diet. According to the authors, the protection conferred by selenium deficiency against aflatoxin $B_{1}$ is associated with the hepatic expression of an aldo-keto reductase and a glutathione S-transferase subunit that efficiently metabolizes the mycotoxin.

Based on a study on rats Atroshi et al. (1995) concluded that selenium, vitamin E and vitamin $\mathrm{C}$ act as an antioxidant system and free radical scavenger that protects spleen and brain against membrane damage caused by T-2 toxin and DON. The same authors, Atroshi et al. (2000) reported a decrease of the GSH activity after a two-week-treatment with ochratoxin in mice. Treatment of mice with the combined antioxidants could enhance the hepatic oxidant/detoxification system, as indicated by an increase in hepatic-reduced glutathione level. The authors suggest that use of the combined antioxidants may be of 
Triglycerides

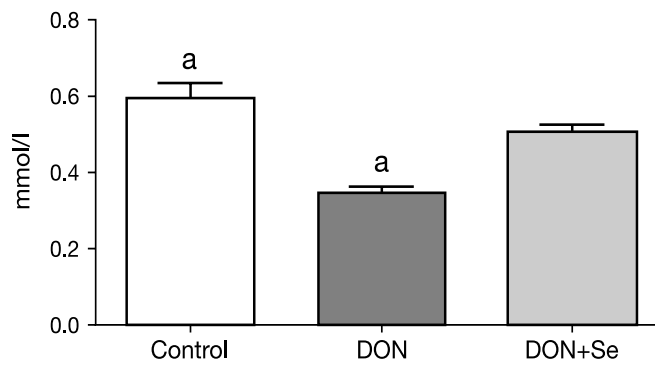

Free glycerol
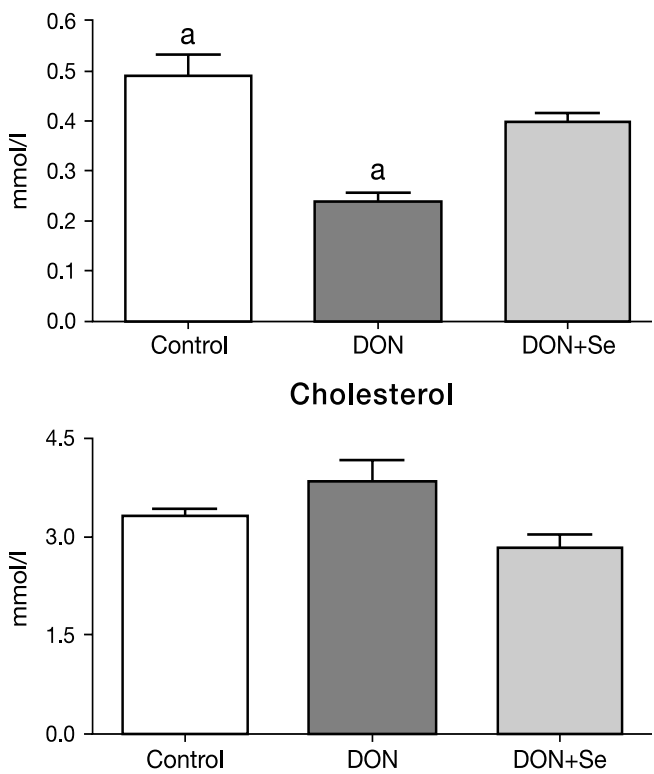

Lactate dehydrogenase

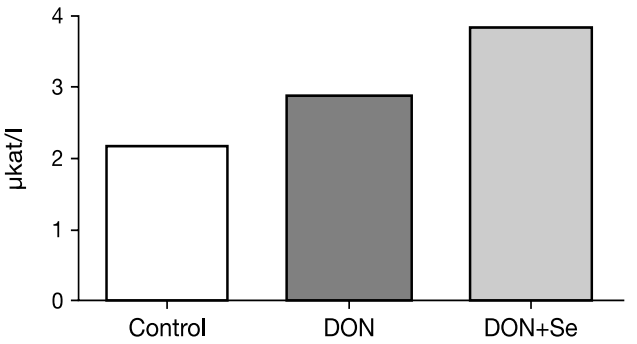

Fig. 2. Plasma triglycerides, free glycerol and cholesterol concentrations and lactate dehydrogenase activity after DON and selenium- enriched yeast intake in chickens. Values are mean \pm S.E.M. $(n=14)$. Significant differences between columns are indicated by using the same superscript letter, $P<0.01$. interest in conditions when certain toxinmediated forms of cell death/apoptosis contribute significantly to toxicity.

A curious fact is that in some cases the source of potential protective agents are also a potential way to the assumption of mycotoxins, especially $\mathrm{AFB}_{1}$ and OTA (Halt 1998). Moreover, caution should be used in promoting antimycotoxin action of discussed substances, since some may have toxic properties (selenium).

Our results show that dietary inclusion of deoxynivalenol resulted in changes of plasma indices in growing broiler chicks. Supplementation of organic selenium counteracted most of the plasma indicator alterations caused by deoxynivalenol in broiler chicks.

\section{Efektívnost' selénu v diéte pôsobit' proti toxicite deoxynivalenolu u rastúcich kurčiat}

Ciel'om práce bolo vyhodnotit' vplyv deoxynivalenolu na ukazovatele $\mathrm{v}$ krvnej plazme rastúcich broilerových kurčiat a stanovit' efektívnost' pôsobenia selénu proti toxicite deoxynivalenolu. $\mathrm{V}$ pokuse boli použité tri skupiny kurčiat; počet kurčiat v každej skupine bol 14. Kontrolná diéta obsahovala 0,2 ppm deoxynivalenolu a $0,4 \mathrm{mg}$ selénu/ $\mathrm{kg}$ diéty, diéta kontaminovaná deoxynivalenolom obsahovala 3 ppm deoxynivalenolu a $0,4 \mathrm{mg}$ selénu/kg diéty a tretia diéta obsahovala 3 ppm deoxynivalenolu a selénom obohatené kvasnice $\mathrm{v}$ dávke $1,4 \mathrm{mg} / \mathrm{kg}$ diéty. Zvieratá boli kŕmené diétami 6 týždňov, potom boli usmrtené a vzorky krvi boli odobraté na chemické vyšetrenia. Koncentrácia vápnika, chloridov a aktivita alanínaminotransferázy boli signifikantne zvýšená a koncentrácia horčíka, celkových bielkovín, triglyceridov a vol'ného glycerolu $\mathrm{v}$ plazme poklesla $\mathrm{u}$ kurčiat kŕmených diétou kontaminovanou deoxynivalenolom $\mathrm{v}$ porovnaní $\mathrm{s}$ kurčatami kŕmenými kontrolnou diétou. Pridanie prípravku obsahujúcom selénom obohatené kvasnice ku diéte eliminovalo zmeny v koncentrácií vápnika, horčíka a aktivity alanínaminotransferázy $\mathrm{v}$ plazme kurčiat 
vyvolané deoxynivalenolom. Koncentrácia fosforu, albumínu, cholesterolu a aktivita alkalickej fosfatázy, aspartátaminotransferázy a laktátdehydrogenázy nebola ovplyvnená diétou. Prídavok selénu ku diéte kontaminovanej deoxynivalenolom však úplne nezmiernil toxický účinok deoxynivalenolu na metabolizmus tukov a bielkovín v pečeni. Prídavok prípravku, ktorý obsahoval selenizované kvasnice zmiernil väčšinu zmien v plazme vyvolaných deoxynivalenolom u kurčiat.

\section{Ackowledgments}

This work was partially supported by the grants VEGA No 1/2443/05, 2/7046/27 and APVT 51004804 .

\section{References}

ATROSHI F, RIZZO A, BIESE I, LINDBERG L, SALONIEMI H 1995: Effects of feeding T-2 toxin and deoxynivalenol on DNA and GSH contents of brain and spleen of rats supplemented with vitamin $\mathrm{E}$ and $\mathrm{C}$ and selenium combination. J Anim Physiol Anim Nutr 74: 157-164

ATROSHI F, RIZZO A, BIESE I, VEIJALAINEN P, SALONIEMI H, SANKARI S, ANDERSSON K 1999: Fumonisin B1-induced DNA damage in rat liver and spleen: effects of pretreatment with coenzyme Q 10, L-carnitine, alpha-tocopherol and selenium. Pharmacol Res 40: 459-467

ATROSHI F, BIESE I, SALONIEMI H, ALI-VEHMAS T, SAARI S, RIZSZO A, VEIJALAINEN P 2000: Significance of apoptosis and its relationship to antioxidants after ochratoxin administration in mice. J Pharm Pharmaceut Sci 3: 281-291

BERGSJØ B, LANGSETH W, NAFSTAD I, JANSEN JH, LARSEN HJS 1993: The effects of naturally deoxynivalenol-contaminated oat on the clinical conditions, blood parameters, performance and carcass composition of growing pigs. Vet Res Commun 17: 283-294

BURGUERA JA, EDDS GT, OSUNA O, 1983: Influence of selenium on aflatoxin B1 or crotalaria toxicity in turkey poults. Am J Vet Res 44: 1714-1717

DIAZ GJ, CORTÉS A, RODÁN L 2005: Evaluation of the efficacy of four additivies against the adverse effect of T-2 toxin in growing broiler chickens. J Appl Poult Res 14: 226-231

DOLL S, GERICKE S, DANICKE S, RAILA J, UEBERSCHAR KH, VALENTA H, SCHNURRBUSCH U, SCHWEIGERT FJ, FLACHOWSKY G 2005: The efficacy of a modified aluminosilicate as a detoxifying agent in Fusarium toxin contaminated maize containing diets for piglets. J Anim Physiol Anim Nutr (Berl) 89: $342-358$

DVORSKA JE, SURAI PF 2004: Protective effect of modified glucomannans against changes in antioxidant systems of quail egg and embryo due to aurofusarin consumption. Asian Australas J Anim Sci 17: 434-440

FARNWORTH ER, HAMILTON RM, THOMPSON BK, TRENHOLM HL, 1983: Liver lipid levels in White Leghorn hens fed diets that contained wheat contaminated by deoxynivalenol (vomitoxin). Poult Sci 62: $832-836$

GOUZE ME, LAFFITTE J, ROUIMI P, LOISEAU N, OSWALD IP, GALTIER P 2006: Effect of various doses of deoxynivalenol on liver xenobiotic metabolizing enzymes in mice. Food Chem Toxicol 44: 476-483

HALT M 1998: Moulds and mycotoxins in herb tea and medicinal plants. Eur J Epidemiol 14: 269-274

JAKHAR KK, SADANA JR 2004: Sequential pathology of experimental aflatoxicosis in quail and the effect of selenium supplementation in modifying the disease process. Mycopathologia 157: 99-109

KUBENA LF, HARVEY RB, CORRIER DE, HUFF WE, PHILLIPS TD 1987: Effect of feeding deoxynivalenol (DON, vomitoxin)-contaminated wheat to female White Leghorn chickens from day old through egg production. Poult Sci 66: 1612-1618

KUBENA LF, HUFF WF, HARVER B, CORRIER DE, PHILLIPS TD, CREGER CR 1988: Influence of ochratoxin A and deoxynivalenol on growing broiler chicks. Poult Sci 67: 253-260

KUBENA LF, EDRINGTON TS, HARVEY RB, BUCKLEY SA, PHILLIPS TD, TOTTINGHAUS GE, CASPER HH 1997: Individual and combined effects of fumonisin $\mathrm{B}_{1}$ present in Fusarium moniliforme culture material and T-2 toxin or deoxynivalenol on broiler chicks. Poult Sci 76: 1239-1247

LIN ZH, LI SG, WU LY, SUN S, LU QW 1994: Antagonistic effect of Se on the T-2 toxin-induced changes in the ultrastructure and mitochondrial function of cultured chicken embryonic chondrocytes. J Clin Biochem Nutr 17: 119-132

MC LEOD R, ELLIS EM, ARTHUR JR, NEAL GE, JUDAH DJ, MANSON MM, HAYES JD 1997: Protection conferred by selenium deficiency against aflatoxin B1 in the rat associated with the hepatic expression of an aldo-keto reductase and glutathione S-transferase subunit that metabolize the mycotoxin. Cancer Res 57: 4257-4266

MEZES M, BARTA M, NAGY G, 1999: Comparative investigation of the effect of T-2 mycotoxin on lipid peroxidation and antioxidant status in different poultry species. Res Vet Sci 66: 19-23

MIKAMI O, YAMAMOTO S, YAMANAKA N, NAKAJIMA Y 2004: Porcine hepatocytes apoptosis and reduction of albumin secretion induced by deoxynivalenol. Toxicology 15: 241-249

PARENT-MASSIN D 2004: Haematotoxicity of trichothecenes. Toxicol Lett 153: 75-81 
PENG SQ, YANG JS 2003: Effect of deoxynivalenol on action potentials of cultured cardiomyocytes and the protective effect of selenium. Zhonghua Yu Fang Yi Xue Za Zhi 37: 423-425

RAYMOND SL, SMITH TK, SWAMY HV 2003: Effects of feeding a blend of grains naturally contaminated with Fusarium mycotoxins on feed intake, serum chemistry and hematology of horses, and efficacy of a polymeric glucomannan mycotoxin adsorbent. J Anim Sci 81: 2123-2130

RODRIGUEZ EM, SANZ MT, ROMERO CD 1994: Critical study of fluorometric determination of selenium in urine. Talanta 12: 2025-2031

ROTTER BA, PRELUSKY DB, PESTKA JJ 1996: Toxicology of deoxynivalenol (vomitoxin). J Toxicol Environ Health 48: 1-34

SERGEEV V, PILIIA NM, KUZMINA EE, AVRENEVA LI, KRAVCHENKO LV, SPIRICHEV VB, TUTELIAN VA 1990: Calcium and vitamin D metabolism and enzymes of xenobiotic metabolism during chronic action of mycotoxins. Vopr Pitan 5: 25-30

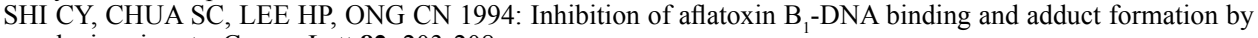
selenium in rats. Cancer Lett 82: 203-208

SHI CY, HEW YC, ONG CN 1995: Inhibition of aflatoxin $\mathrm{B}_{1}$-induced cell injury by selenium: an in vitro study. Hum Exp Toxicol 14: 55-60

SWAMY HV, SMITH TK, COTTER PF, BOERMANS HJ, SEFTON AE 2002: Effects of feeding blends of grains naturally contaminated with Fusarium mycotoxins on production and metabolism in broilers. Poult Sci 81: $966-975$ 